\title{
Compositional Effect on Soft Magnetic Properties of Co-Fe-Si-B Amorphous Alloys with Zero Magnetostriction
}

\author{
By Akihiro Makino*, Akihisa Inoue** and Tsuyoshi Masumoto**
}

\begin{abstract}
The compositional effect on magnetic properties of $\mathrm{Co}-\mathrm{Fe}-\mathrm{Si}-\mathrm{B}$ amorphous alloys was examined with the aim of finding an optimum composition for a magnetic head material. The lowest coercivity $\left(H_{c}\right)$ and the highest permeability at $0.3 \mathrm{kHz}\left(\mu_{0.3}\right)$ in the as-quenched state were obtained at $0.94 \mathrm{Co} /(\mathrm{Co}+\mathrm{Fe})$ and in the metalloid range of 24 to $25 \%(\mathrm{Si}+\mathrm{B})$ and $0.6 \mathrm{Si} /(\mathrm{Si}+\mathrm{B})$. The composition range is in agreement with that in which the highest glass-forming capacity is obtained and hence the good soft magnetic properties in the limited composition range are presumably due to a high degree of amorphicity and structural homogeneity. The permeability at $100 \mathrm{kHz}\left(\mu_{100}\right)$ shows a maximum value in the range of $27 \%(\mathrm{Si}+\mathrm{B})$ and 0.65 to $0.70 \mathrm{Si} /(\mathrm{Si}+\mathrm{B})$ and the difference of the optimum compositions between $\mu_{0.3}$ and $\mu_{100}$ is due to the necessity of high electrical resistivity for $\mu_{100}$. The annealing results in the change of the optimum composition to $0.6 \mathrm{Si} /(\mathrm{Si}+\mathrm{B})$ for $\mu_{100}$ and $0.5 \mathrm{Si} /(\mathrm{Si}+\mathrm{B})$ for $H_{\mathrm{c}}$. The annealing-induced change is interpreted from the difference in the compositional effect on the homogeneity and thermal stability of the amorphous structure. Thus, the combination of high magnetization values of $98 \times 10^{-6}$ to $113 \times 10^{-6}$ wb.m.kg ${ }^{-1}$ and high permeability at $0.3 \mathrm{kHz}$ reaching $19.21 \times 10^{4}$ in the annealed state is achieved at $0.6 \mathrm{Si} /(\mathrm{Si}+\mathrm{B})$ where the amorphous structure has high thermal stability and hence the metalloid composition is concluded to be optimum for an amorphous magnetic head material.
\end{abstract}

(Received June 11, 1990)

Keywords: amorphous ribbon, cobalt-iron-silicon-boron system, soft magnetic property, zero magnetostriction, permeability, coercivity, saturation magnetization, compositional effect

\section{Introduction}

Since ferromagnetic properties of melt-spun $\mathrm{Co}-\mathrm{Fe}-$ $\mathrm{Si}-\mathrm{B}$ amorphous alloys were reported for the first time in $1974^{(1)}$, a number of studies on the magnetic properties of ( $\mathrm{Fe}, \mathrm{Co}, \mathrm{Ni}$ )-Si-B amorphous alloys have been carried out ${ }^{(2)(3)}$, leading to the finding of excellent soft ferromagnetic properties for a $\mathrm{Co}-\mathrm{Fe}-\mathrm{Si}-\mathrm{B}$ amorphous alloy with zero magnetostriction. The zero magnetostrictive $\mathrm{Co}-\mathrm{Fe}-\mathrm{Si}-\mathrm{B}$ amorphous alloy has attracted great attention in a practical use as a magnetic head material ${ }^{(4)-(7)}$ because of high electrical resistivity and high hardness as well as good soft magnetic properties. Although various kinds of characteristics are required for magnetic head materials, the most important characteristics are due to the simultaneous satisfaction of high saturation magnetization and high permeability ${ }^{(8)}$. However, little has been known about the compositional effect on the magnetic properties of zero magnetostrictive $\mathrm{Co}-\mathrm{Fe}-\mathrm{Si}$ $\mathrm{B}$ amorphous alloys. This paper is intended to examine the compositional dependence of magnetic properties (coercivity, permeability and saturation magnetization) in rapidly solidified and annealed states for zero magnetostrictive $\mathrm{Co}-\mathrm{Fe}-\mathrm{Si}-\mathrm{B}$ amorphous alloys and to find an optimum alloy composition at which high satura-

* Research and Development, Alps Electric Co., Ltd., Nagaoka 940, Japan.

** Institute for Materials Research, Tohoku University, Sendai 980, Japan. tion magnetization and good soft magnetic properties are obtained simultaneously.

\section{Experimental Procedure}

$\mathrm{Co}-\mathrm{Fe}-\mathrm{Si}-\mathrm{B}$ ingots in the composition range of 0.9 to $1.0 \mathrm{Co} /(\mathrm{Co}+\mathrm{Fe}), 22$ to $27 \mathrm{at} \%(\mathrm{Si}+\mathrm{B})$ and 0.2 to $0.7 \mathrm{Si} /(\mathrm{Si}+\mathrm{B})$ were produced by induction melting a mixture of pure cobalt ( 99.9 mass $\%)$ and iron ( 99.9 mass\%) metals, silicon ( 99.999 mass\%) and boron ( 99.8 mass\%) in an alumina crucible in an argon atmosphere, followed by casting into a copper mold with an inner diameter of $30 \mathrm{~mm}$. From the ingots, rapidly solidified ribbons with a thickness ranging from 45 to $50 \mu \mathrm{m}$ and a width of 24 $\mathrm{mm}$ were produced in air by a single roller melt spinning method. The amorphicity of the ribbons was examined by X-ray diffractometry using Co $K \alpha$ radiation and transmission electron microscopy (TEM). The permeability $\left(\mu_{\mathrm{e}}\right)$ was measured at a frequency of 0.3 or $100 \mathrm{kHz}$ under an applied field of 0.239 or $0.796 \mathrm{~A} / \mathrm{m}$ by the trance method for the ring samples with an inner and an outer diameter of 6 and $10 \mathrm{~mm}$, respectively, produced by either chemical etching or mechanical punching the wide amorphous ribbons. Measurement of coercivity $\left(H_{\mathrm{c}}\right)$ was made for the same ring samples by using a B-H loop tracer. Saturation magnetization $\left(\sigma_{\mathrm{s}}\right)$ was measured under an applied field of $39.8 \mathrm{kA} / \mathrm{m}(500 \mathrm{Oe})$ at room temperature with a vibrating sample megnetometer. Magnetostriction was evaluated by measuring the elongation of sample under an applied field of $79.6 \mathrm{kA} / \mathrm{m}$ with a strain gauge meter. Electrical resistivity was measured 
at room temperature by the DC four-probe technique. Annealing treatment was made for $600 \mathrm{~s}$ at different temperatures in an argon atmosphere followed by water quenching. Crystallization temperature and heat of crystallization were measured at a scanning rate of 0.33 $\mathrm{K} / \mathrm{s}$ by differential scanning calorimetry (DSC) and the onset temperature of exothermic peak due to crystallization was defined as crystallization temperature $\left(T_{\mathrm{x}}\right)$.

\section{Results and Discussion}

\section{Magnetic properties in a rapidly solidified state}

Figure 1 shows the changes in $\mu_{\mathrm{e}}$ at $0.3 \mathrm{kHz}$ and 0.239 or $0.796 \mathrm{~A} / \mathrm{m}\left(\mu_{0.3}\right)$ and $H_{\mathrm{c}}$ as a function of concentration ratio of $\mathrm{Co}$ to $\mathrm{Co}+\mathrm{Fe}$ for $\mathrm{Co}-\mathrm{Fe}-\mathrm{Si}-\mathrm{B}$ amorphous alloys. The compositional dependences of $\mu_{0.3}$ and $H_{\mathrm{c}}$ are considerably larger for the alloys with higher ratios of $\mathrm{Si} /(\mathrm{Si}+\mathrm{B})$ than for the alloys with lower $\mathrm{Si}$ concentrations and the former alloys exhibit an increase of $\mu_{0.3}$ and a decrease of $H_{c}$ at a limited composition of $0.940 \mathrm{Co} /(\mathrm{Co}+\mathrm{Fe})$. Similarly, the latter alloys also tend to have high $\mu_{0.3}$ and low $H_{\mathrm{c}}$ in the $\mathrm{Co} /(\mathrm{Co}+\mathrm{Fe})$ range of 0.940 to 0.945 . It is known that magnetostriction affects significantly soft magnetic properties and the approach of magnetostriction to zero value is an essential factor to achieve good soft magnetic properties of high $\mu_{\mathrm{e}}$ and low $H_{\text {c. }}$ Considering previous data ${ }^{(9)(10)}$ that zero magnetostriction is obtained for $\left(\mathrm{Co}_{0.96} \mathrm{Fe}_{0.04}\right)_{100-x-y} \mathrm{Si}_{x} \mathrm{~B}_{y}$ amorphous alloys, the good soft magnetic properties in the vicinity of $0.94 \mathrm{Co} /(\mathrm{Co}+\mathrm{Fe})$ seem to result from nearly zero magnetostriction. The systematic compositional dependence of $\mu_{0.3}$ suggests that the concentration ratio of Co to $\mathrm{Co}+\mathrm{Fe}$ exhibiting zero magnetostriction remains almost constant of 0.94 in a rather wide metalloid composition range of 23 to 27 at $\%(\mathrm{Si}+\mathrm{B})$ and 0.20 to $0.64 \mathrm{Si} /(\mathrm{Si}+\mathrm{B})$, in agreement with the previous data ${ }^{(11)(12)}$ on the effect of metalloid composition on the optimum ratio of $\mathrm{Co} /(\mathrm{Co}+\mathrm{Fe})$ exhibiting zero magnetostriction for $\mathrm{Co}-$ $\mathrm{Fe}-\mathrm{Si}-\mathrm{B}$ amorphous alloys. On the basis of the compositional dependences of $\mu_{0.3}$ and $H_{\mathrm{c}}$ shown in Fig. 1, a subsequent study of finding an optimum metalloid composition for the production of an excellent soft magnetic material was performed in the series of $\left(\mathrm{Co}_{0.94} \mathrm{Fe}_{0.06}\right)_{100-x-y} \mathrm{Si}_{x} \mathrm{~B}_{y}$ alloys with a constant $\mathrm{Co} /(\mathrm{Co}+\mathrm{Fe})$ value of 0.94 .

Figures 2 and 3 show the changes in $H_{\mathrm{c}}$ and $\mu_{0.3}$ for $\left(\mathrm{Co}_{0.94} \mathrm{Fe}_{0.06}\right)_{100-x-y} \mathrm{Si}_{x} \mathrm{~B}_{y}$ amorphous alloys with metalloid composition. As is evident from the contour lines shown in Fig. 2, the $H_{\mathrm{c}}$ value is the lowest $(0.96 \mathrm{~A} / \mathrm{m})$ at $25 \%(\mathrm{Si}+\mathrm{B})$ and $0.60 \mathrm{Si} /(\mathrm{Si}+\mathrm{B})$ and increases with a deviation from the composition. The increase in $H_{\mathrm{c}}$ is more remarkable in the higher $\mathrm{Si} /(\mathrm{Si}+\mathrm{B})$ range. Similarly, the $\mu_{0.3}$ also shows the highest value of 18700 at $24 \%(\mathrm{Si}+\mathrm{B})$ and $0.6 \mathrm{Si} /(\mathrm{Si}+\mathrm{B})$ and decreases with a deviation from the composition. It is notable that the combined characteristics of low $H_{\mathrm{c}}$ and high $\mu_{0.3}$ are obtained in the vicinity of 24 to $25 \%(\mathrm{Si}+\mathrm{B})$ and $0.6 \mathrm{Si} /(\mathrm{Si}+\mathrm{B})$. In order to clarify the reason for the com-

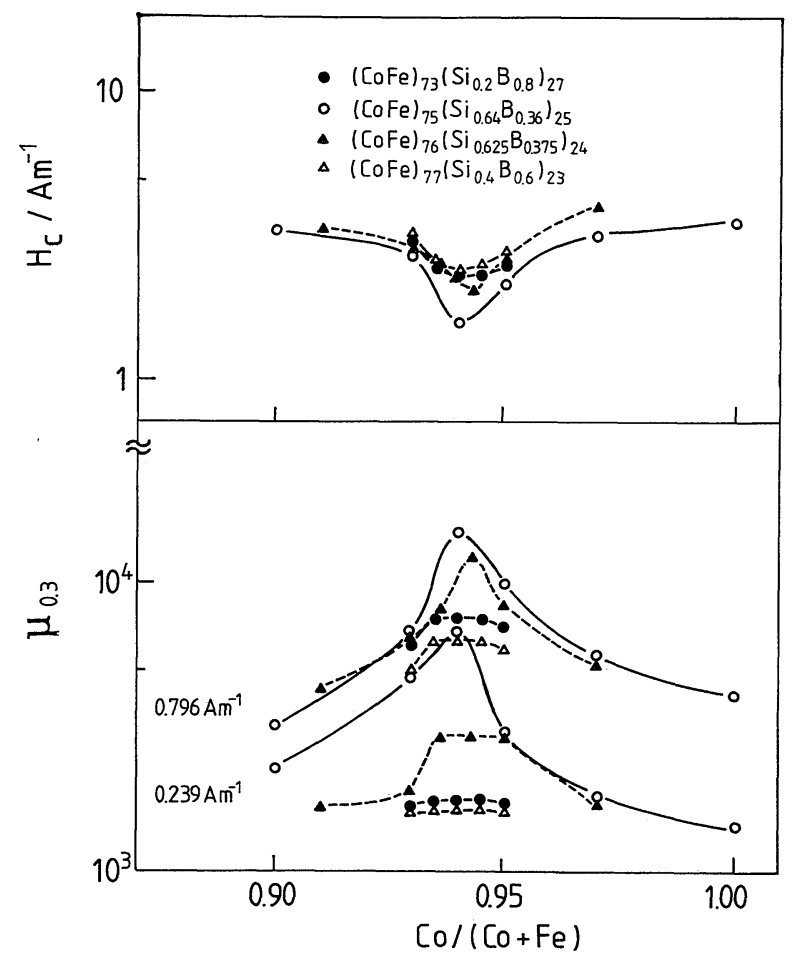

Fig. 1 Changes in the permeability $\left(\mu_{0.3}\right)$ at $0.3 \mathrm{kHz}$ and coercivity $\left(H_{\mathrm{c}}\right)$ as a function of $\mathrm{Co} /(\mathrm{Co}+\mathrm{Fe})$ for as-quenched $\mathrm{Co}-\mathrm{Fe}-\mathrm{Si}-\mathrm{B}$ amorphous alloys.

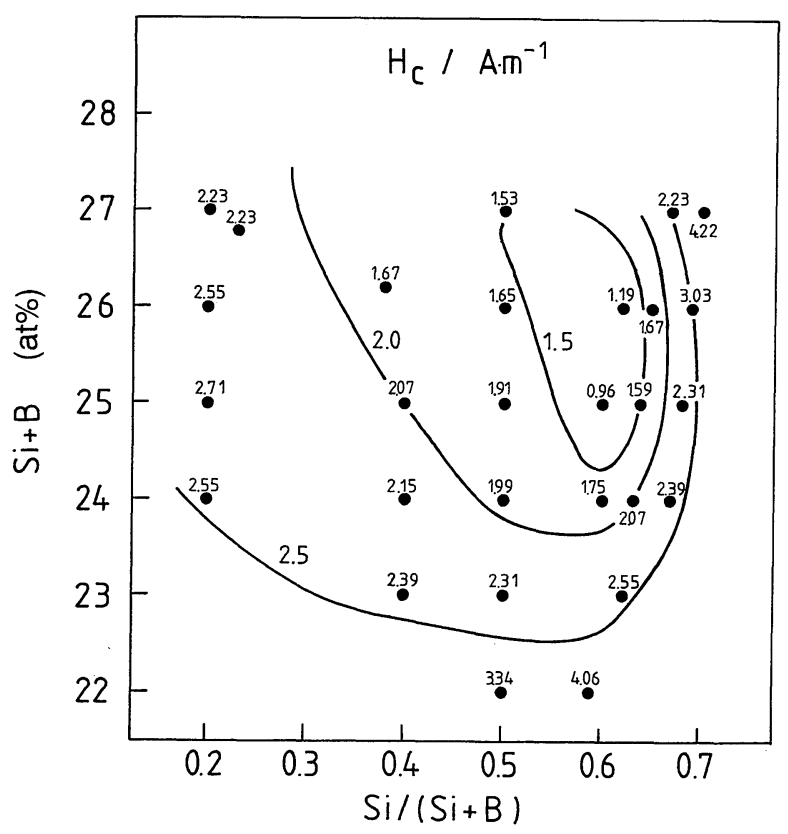

Fig. 2 Change in the coercivity $\left(H_{\mathrm{c}}\right)$ as a function of $\mathrm{Si}+\mathrm{B}$ and $\mathrm{Si} /(\mathrm{Si}+\mathrm{B})$ for as-quenched $\left(\mathrm{Co}_{0.94} \mathrm{Fe}_{0.06}\right)_{100-x-y} \mathrm{Si}_{x} \mathrm{~B}_{y}$ amorphous alloys.

positional effects of $H_{\mathrm{c}}$ and $\mu_{0.3}$ for $\left(\mathrm{Co}_{0.94} \mathrm{Fe}_{0.06}\right)_{100-x-y} \mathrm{Si}_{x}$ $\mathrm{B}_{y}$ amorphous alloys, the measurement of magnetostriction was made and the magnetostriction was confirmed to be of the order $10^{-7}$ for almost all the quaternary alloys examined in the present study. However, the compositional dependence of the magnetostriction in the very 


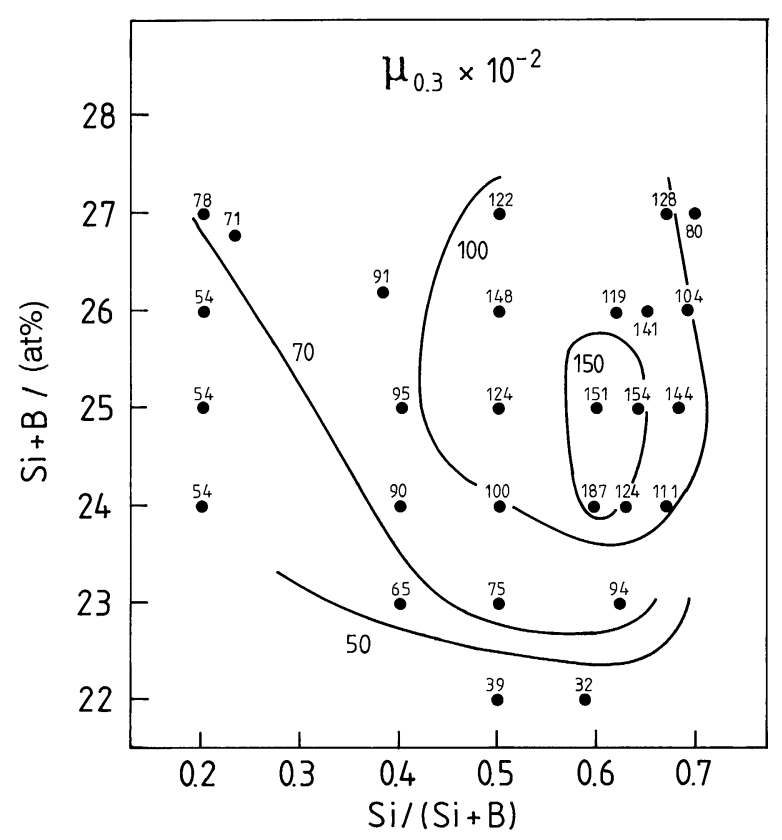

Fig. 3 Change in the permeability at $0.3 \mathrm{kHz}$ and $0.796 \mathrm{~A} / \mathrm{m}$ $\left(\mu_{0.3}\right)$ as a function of $\mathrm{Si}+\mathrm{B}$ and $\mathrm{Si} /(\mathrm{Si}+\mathrm{B})$ for as-quenched $\left(\mathrm{Co}_{0.94} \mathrm{Fe}_{0.06}\right)_{100-x-y} \mathrm{Si}_{x} \mathrm{~B}_{y}$ amorphous alloys.

small values of $10^{-7}$ could not be clarified because of significant scattering resulting from the very small magnetostriction values. Judging from the very small magnetostriction, which can be regarded as a nearly zero magnetostriction, in the $\mathrm{Co}-\mathrm{Fe}-\mathrm{Si}-\mathrm{B}$ amorphous alloys with a constant $\mathrm{Co} /(\mathrm{Co}+\mathrm{Fe})$ value of 0.94 , the compositional dependences of $\mu_{0.3}$ and $H_{\mathrm{c}}$ shown in Figs. 2 and 3 seem to reflect the degrees of amorphicity and microscopic structural homogeneity in the rapidly solidified amorphous state.

Here, it appears important to point out that the metalloid composition of 24 to $25 \%(\mathrm{Si}+\mathrm{B})$ and $0.6 \mathrm{Si} /(\mathrm{Si}+\mathrm{B})$ agrees well with that ${ }^{(13)}$ having the largest glass-forming capacity in Co-Si-B ternary alloys. As shown in Fig. 4, the large critical ribbon thickness $\left(t_{c}\right)$ for the formation of an amorphous phase exceeding $145 \mu \mathrm{m}$ has been obtained in the range of 25 to $27 \%(\mathrm{Si}+\mathrm{B})$ and $0.60 \mathrm{Si} /(\mathrm{Si}+\mathrm{B})^{(13)}$. The total amount of $\mathrm{Si}$ and $\mathrm{B}$ in the amorphous alloy exhibiting the largest $t_{\mathrm{c}}$ value is slightly larger than that (24 to $25 \%$ ) for the amorphous alloy with the best soft magnetic properties. It has previously been reported ${ }^{(13)}$ that the largest $t_{\mathrm{c}}$ value in $\mathrm{Co}-\mathrm{Si}-\mathrm{B}$ and Fe-Si-B ternary systems is obtained at $\mathrm{Co}_{72.5} \mathrm{Si}_{12.5} \mathrm{~B}_{15}$ and $\mathrm{Fe}_{77.5} \mathrm{Si}_{10} \mathrm{~B}_{12.5}$ and the optimum metalloid content leading to the largest glass-forming capacity is considerably less for Co-Si-B alloys. Accordingly, the slight difference in the metalloid compositions at which the largest $t_{\mathrm{c}}$ value and the best soft magnetic properties are obtained seems to result from the replacement of $\mathrm{Co}$ by $6 \% \mathrm{Fe}$. It is generally thought that the larger the glass-forming capacity the higher are the noncrystallinity and homogeneity of the amorphous phase in the melt-spun ribbon with a constant thickness. Accordingly, the agreement of the metalloid composition between the best soft magnetic

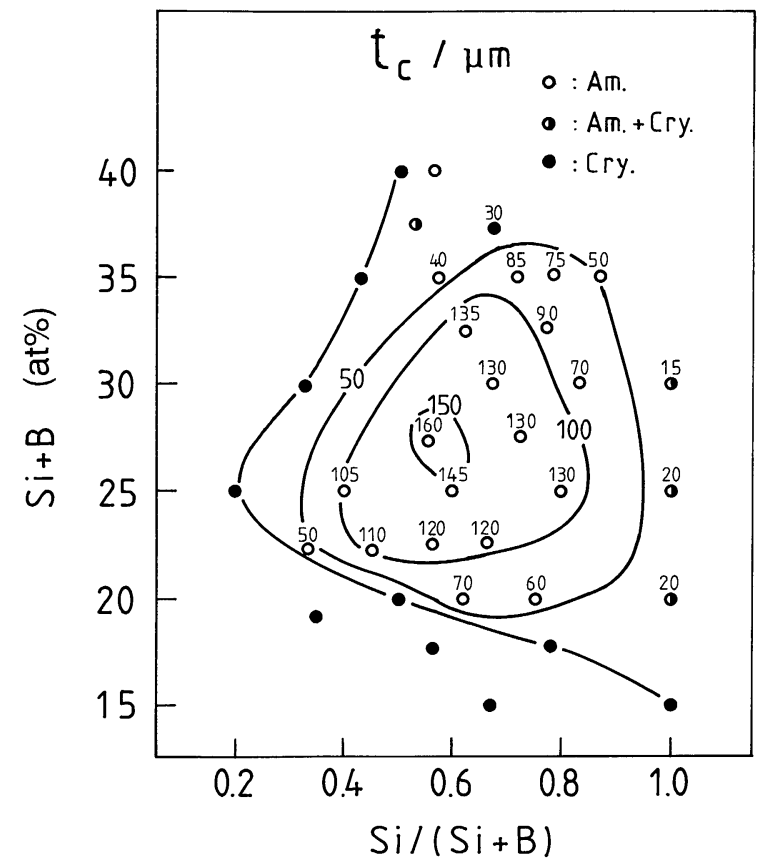

Fig. 4 Change in the critical ribbon thickness $\left(t_{c}\right)$ for formation of an amorphous phase as a function of $\mathrm{Si}+\mathrm{B}$ and $\mathrm{Si} /(\mathrm{Si}+\mathrm{B})$ for asquenched $\mathrm{Co}-\mathrm{Si}-\mathrm{B}$ amorphous alloys.

properties and the largest glass-forming capacity allows us to presume that the best soft magnetic properties in the range of 24 to $25 \%(\mathrm{Si}+\mathrm{B})$ and $0.6 \mathrm{Si} /(\mathrm{Si}+\mathrm{B})$ are due to the reduction of magnetic anisotropy resulting from a high degree of noncrystallinity and homogeneity in the amorphous phase caused by the largest glass-forming capacity. However, the details in the variations of $H_{\mathrm{c}}$ and $\mu_{0.3}$ with metalloid composition do not always agree with that for the $t_{\mathrm{c}}$. The difference in the variations of $t_{\mathrm{c}}$ and $H_{\mathrm{c}}$ or $\mu_{0.3}$ with metalloid composition appears to result from the differences in metallic component and liquidquenching condition.

Figure 5 shows the change in $\mu_{\mathrm{e}}$ at $100 \mathrm{kHz}\left(\mu_{100}\right)$ for $\left(\mathrm{Co}_{0.94} \mathrm{Fe}_{0.06}\right)_{100-x-y} \mathrm{Si}_{x} \mathrm{~B}_{y}$ amorphous alloys with metalloid composition. The $\mu_{100}$ value at the high frequency was very sensitive to sample thickness and hence the data shown in Fig. 5 were obtained for the amorphous ribbons with a nearly constant thickness ranging from 45 to $50 \mu \mathrm{m}$. As the metalloid content increases, the $\mu_{100}$ increases and shows high values above 6000 for $\left(\mathrm{Co}_{0.94} \mathrm{Fe}_{0.06}\right)_{73} \mathrm{Si}_{27-x} \mathrm{~B}_{x}$ with $\mathrm{Si} /(\mathrm{Si}+\mathrm{B})$ ratios ranging from 0.65 to 0.70 . In comparison with the $\mu_{0.3}$ values shown in Fig. 3, the increase of frequency from 0.3 to $100 \mathrm{kHz}$ brings about the shift of the composition, at which the largest $\mu_{\mathrm{e}}$ value is obtained, to the higher composition range. This shift is explained by taking the compositional dependence of electrical resistivity into consideration. As shown in Fig. 6, the electrical resistivity at room temperature $\left(\rho_{\mathrm{RT}}\right)$ increases significantly from about 110 to 150 $\times 10^{-8} \Omega \mathrm{m}$ with an increase of total metalloid content and the ratio of $\mathrm{Si} /(\mathrm{Si}+\mathrm{B})$. Although the $\mu_{0.3}$ is independent of $\rho_{\mathrm{RT}}$, the $\mu_{100}$ at the high frequency is usually dependent on $\rho_{\mathrm{RT}}$ and tends to increase with increasing $\rho_{\mathrm{RT}}$ because 


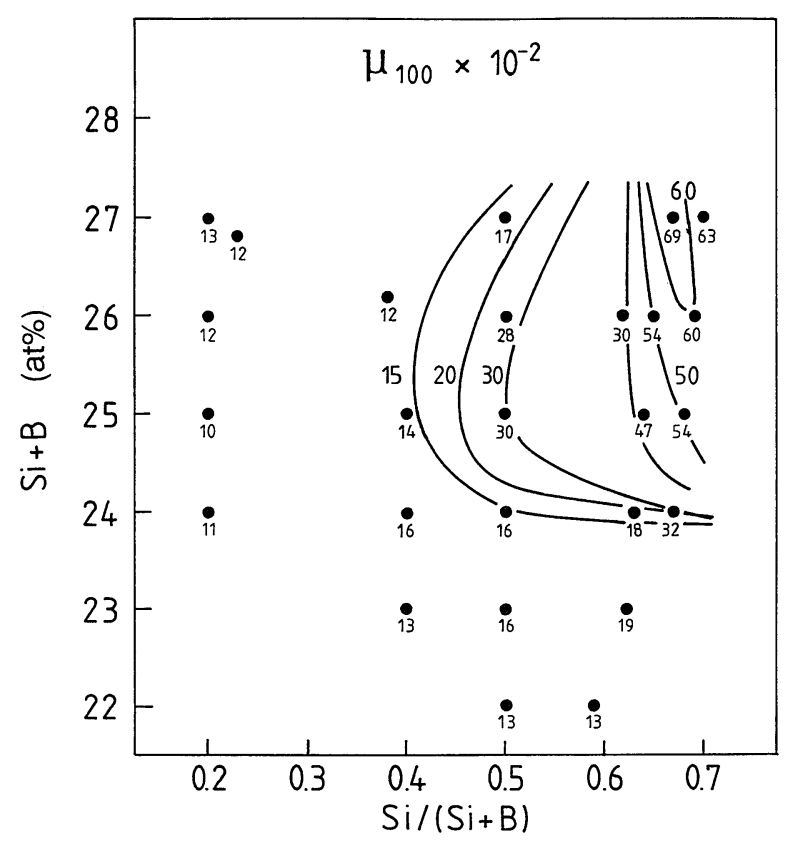

Fig. 5 Change in the permeability at $100 \mathrm{kHz}$ and $0.796 \mathrm{~A} / \mathrm{m}$ $\left(\mu_{100}\right)$ as a function of $\mathrm{Si}+\mathrm{B}$ and $\mathrm{Si} /(\mathrm{Si}+\mathrm{B})$ for as-quenched $\left(\mathrm{Co}_{0.94} \mathrm{Fe}_{0.06}\right)_{100-x-y} \mathrm{Si}_{x} \mathrm{~B}_{y}$ amorphous alloys.

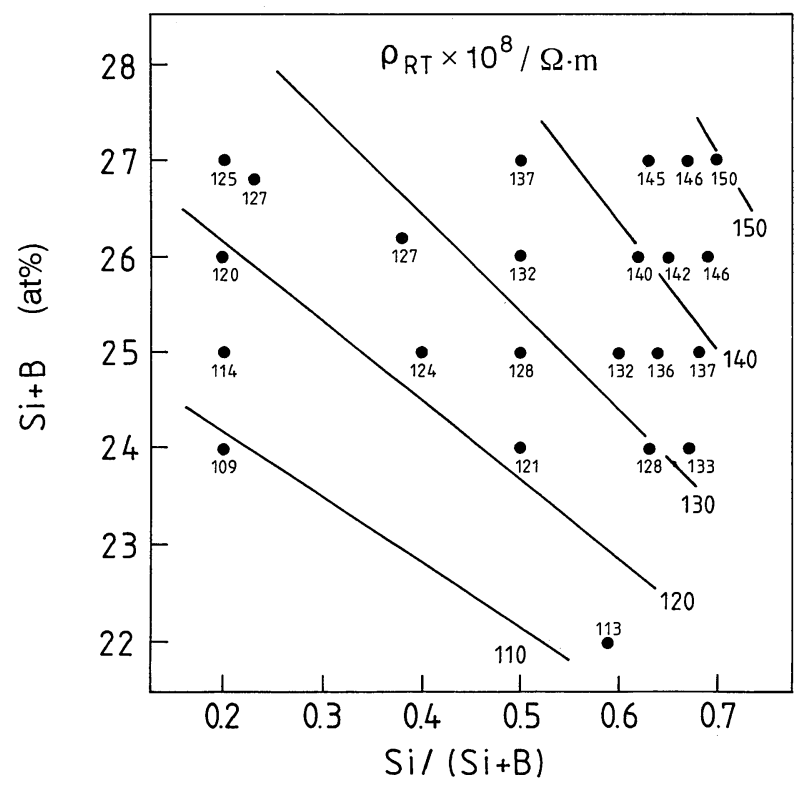

Fig. 6 Change in the electrical resistivity at room temperature $\left(\rho_{\mathrm{RT}}\right)$ as a function of $\mathrm{Si}+\mathrm{B}$ and $\mathrm{Si} /(\mathrm{Si}+\mathrm{B})$ for as-quenched $\left(\mathrm{Co}_{0.94} \mathrm{Fe}_{0.06}\right)_{100-x-y} \mathrm{Si}_{x} \mathrm{~B}_{y}$ amorphous alloys.

of a decrease of eddy current loss. Accordingly, the achievement of the largest $\mu_{100}$ in the higher metalloid range is presumably due to the overlap of the compositional dependences of $\mu_{\mathrm{e}}$ and $\rho_{\mathrm{RT}}$.

\section{Magnetic properties in an annealed state}

(1) Change in magnetic properties with annealing temperature and alloy composition

It is generally known that as-quenched amorphous alloys do not exhibit the best soft magnetic properties because of the hindrence of the movement of magnetic walls due to quenching-induced internal stress. The annealing treatment consisting of heating in a temperature range between Curie temperature $\left(T_{\mathrm{c}}\right)$ and the onset temperature of crystallization $\left(T_{\mathrm{x}}\right)$ and subsequent water quenching has been reported to bring about an improvement of soft magnetic properties ${ }^{(14)}$. A similar heating treatment was made for the $\left(\mathrm{Co}_{0.94} \mathrm{Fe}_{0.06}\right)_{100-x-y} \mathrm{Si}_{x} \mathrm{~B}_{y}$ amorphous alloys with the aim of improving soft magnetic properties. Figure 7 shows the change of the $\mu_{0.3}$ as a function of annealing temperature $\left(T_{\mathrm{a}}\right)$ for $\left(\mathrm{Co}_{0.94} \mathrm{Fe}_{0.06}\right)_{75}\left(\mathrm{Si}_{x} \mathrm{~B}_{y}\right)_{25}$ amorphous alloys having $T_{\mathrm{x}}$ values considerably higher than $T_{\mathrm{c}}$. The heating time at each $T_{\mathrm{a}}$ was fixed to be $600 \mathrm{~s}$. When $T_{\mathrm{a}}$ is lower than $T_{\mathrm{c}}$, the $\mu_{0.3}$ decreases as compared with that of the as-quenched samples. However, the increase of $T_{\mathrm{a}}$ to the temperature range between $T_{\mathrm{c}}$ and $T_{\mathrm{x}}$ gives rise to $\mu_{0.3}$ values higher than those of the as-quenched samples. The highest $\mu_{0.3}$ value in an annealed state is $14.11 \times 10^{4}$ for $\left(\mathrm{Co}_{0.94} \mathrm{Fe}_{0.06}\right)_{75}$ $\mathrm{Si}_{15} \mathrm{~B}_{10}$ annealed at $700 \mathrm{~K}$. It is thus notable that the alloy with the highest $\mu_{0.3}$ in an as-quenched state exhibits the largest $\mu_{0.3}$ even in the annealed state. The data shown in Fig. 7 also indicate that the optimum $T_{\mathrm{a}}$ leading to the highest $\mu_{0.3}$ value tends to decrease with an increase of the ratio of $\mathrm{Si} /(\mathrm{Si}+\mathrm{B})$.

An optimum metallic composition in an annealed state was also investigated for $\mathrm{Co}-\mathrm{Fe}-\mathrm{Si}-\mathrm{B}$ amorphous alloys with different metalloid compositions. Figure 8 shows the changes in $\mu_{0.3}$ and $H_{\mathrm{c}}$ as a function of $\mathrm{Co} /(\mathrm{Co}+\mathrm{Fe})$ for $\mathrm{Co}-\mathrm{Fe}-\mathrm{Si}-\mathrm{B}$ amorphous alloys annealed at temperatures between $T_{\mathrm{c}}$ and $T_{\mathrm{x}}$. The combined characteristics of the highest $\mu_{\mathrm{e}}$ and the lowest $H_{\mathrm{c}}$ are obtained at $0.94 \mathrm{Co} /(\mathrm{Co}+\mathrm{Fe})$, in agreement with that for the asquenched samples. It is therefore concluded that there is no appreciable difference in the metallic composition

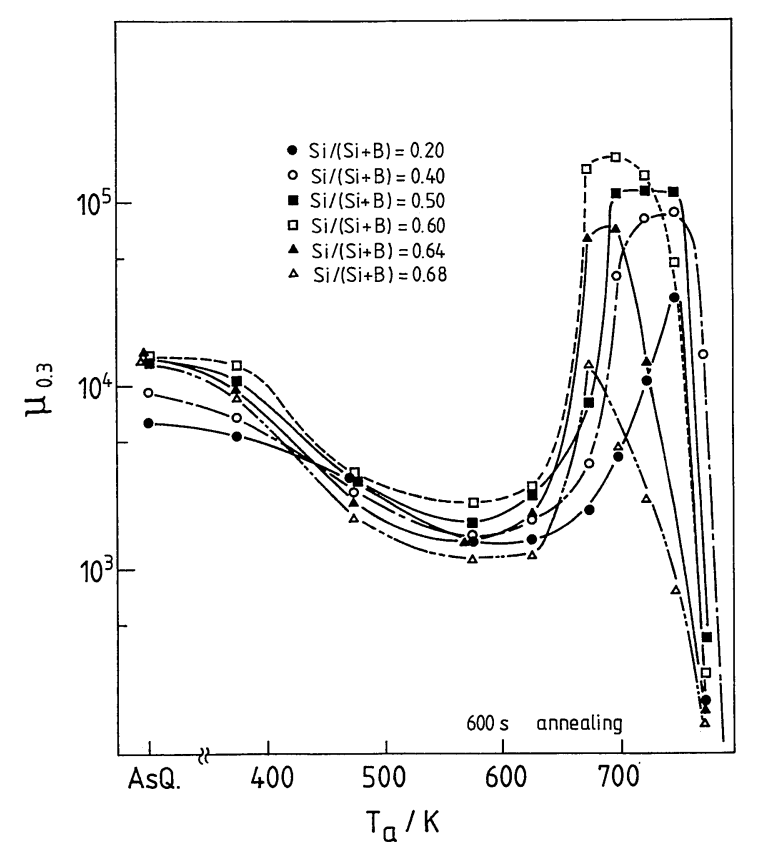

Fig. 7 Change in $\mu_{0.3}$ for $\left(\mathrm{Co}_{0.94} \mathrm{Fe}_{0.06}\right)_{75} \mathrm{Si}_{x} \mathrm{~B}_{25-x}$ amorphous alloys with annealing temperature $\left(T_{\mathrm{a}}\right)$. 


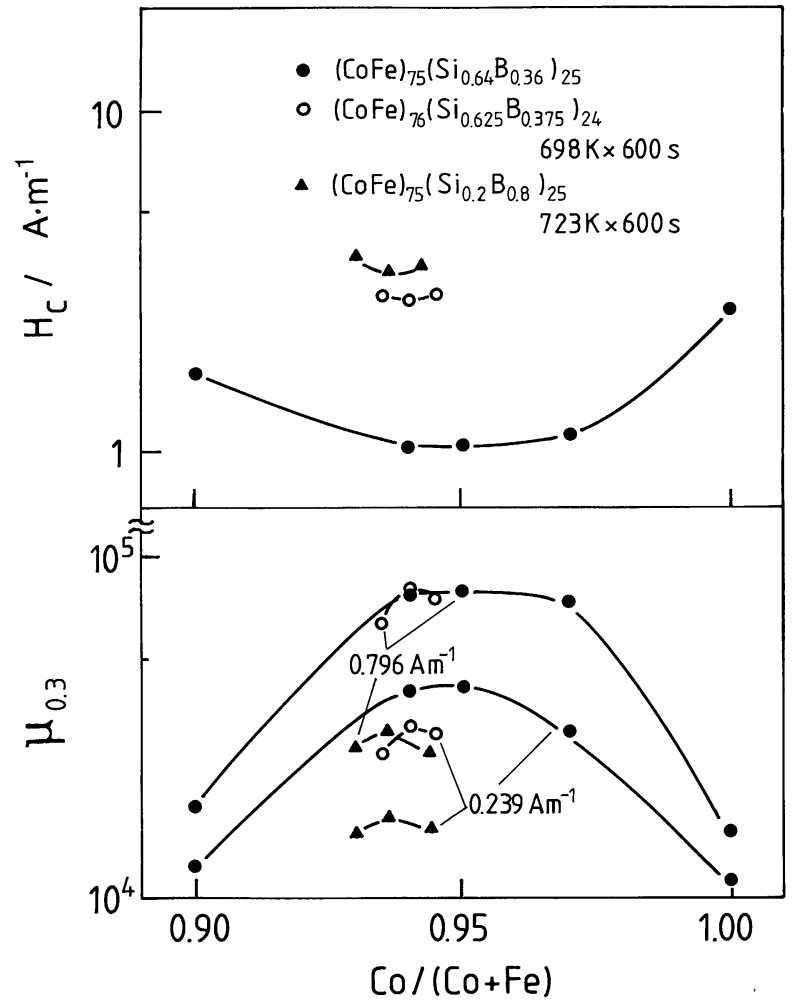

Fig. 8 Changes in $\mu_{0.3}$ and $H_{\mathrm{c}}$ for annealed Co-Fe-Si-B amorphous alloys with $\mathrm{Co} /(\mathrm{Co}+\mathrm{Fe})$.

leading to the best soft magnetic properties between the as-quenched and annealed states. Figures 9 and 10 show the metalloid dependences of the minimum $H_{\mathrm{c}}$ and the maximum $\mu_{0.3}$ values, respectively, for $\left(\mathrm{Co}_{0.94} \mathrm{Fe}_{0.06}\right)_{100-x-y}$ $\mathrm{Si}_{x} \mathrm{~B}_{y}$ amorphous alloys subjected to the optimum annealing treatment. The lowest $H_{\mathrm{c}}$ value of $0.43 \mathrm{~A} / \mathrm{m}$ is obtained in the range of $27 \%(\mathrm{Si}+\mathrm{B})$ and $0.5 \mathrm{Si} /$ $(\mathrm{Si}+\mathrm{B})$ which is different from that $(25 \%(\mathrm{Si}+\mathrm{B})$ and $0.6 \mathrm{Si} /(\mathrm{Si}+\mathrm{B}))$ in the as-quenched state. Similarly, the alloy with $26 \%(\mathrm{Si}+\mathrm{B})$ and $0.6 \mathrm{Si} /(\mathrm{Si}+\mathrm{B})$ exhibits the highest $\mu_{0.3}$ value of $19.21 \times 10^{4}$. In comparison with the metalloid composition exhibiting the lowest $H_{\mathrm{c}}$ and the highest $\mu_{0.3}$ in the as-quenched state, the annealing treatment was concluded to bring about the shifts of the optimum metalloid composition into the higher metalloid content and the optimum $\mathrm{Si} /(\mathrm{Si}+\mathrm{B})$ ratio into the lower value $(\simeq 0.5)$. The shift of the optimum metalloid composition by annealing is presumably because the annealing-induced change of the noncrystallinity, homogeneity and thermal stability in the amorphous structure differs with metalloid composition.

In order to investigate the reason for the shift of the optimum metalloid composition, the change in $T_{\mathrm{x}}$ of $\left(\mathrm{Co}_{0.94} \mathrm{Fe}_{0.06}\right)_{100-x-y} \mathrm{Si}_{x} \mathrm{~B}_{y}$ amorphous alloys with metalloid composition was examined. As shown in Fig. 11, $T_{\mathrm{x}}$ increases significantly from 730 to $817 \mathrm{~K}$ with an increase of total metalloid content from 22 to $27 \%$ and a decrease of $\mathrm{Si} /(\mathrm{Si}+\mathrm{B})$ ratio from 0.7 to 0.6 and there is no significant change in $T_{\mathrm{x}}$ with $\mathrm{Si} /(\mathrm{Si}+\mathrm{B})$ in the range below 0.6. Thus, the compositional dependence of $T_{\mathrm{x}}$ is very steep in

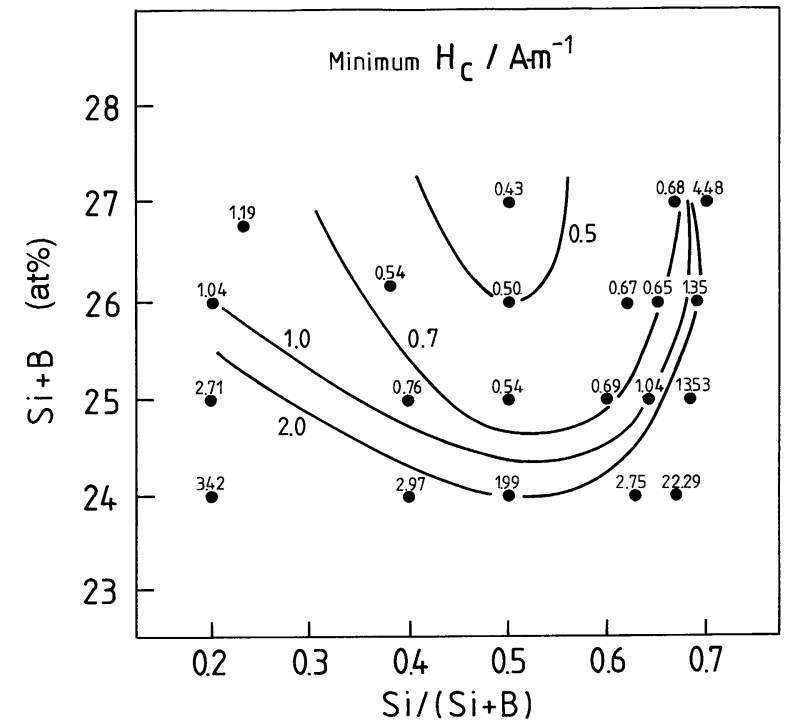

Fig. 9 Change in the minimum $H_{\mathrm{c}}$ as a function of $\mathrm{Si}+\mathrm{B}$ and $\mathrm{Si} /(\mathrm{Si}+\mathrm{B})$ for annealed $\left(\mathrm{Co}_{0.94} \mathrm{Fe}_{0.06}\right)_{100-x-y} \mathrm{Si}_{x} \mathrm{~B}_{y}$ amorphous alloys.

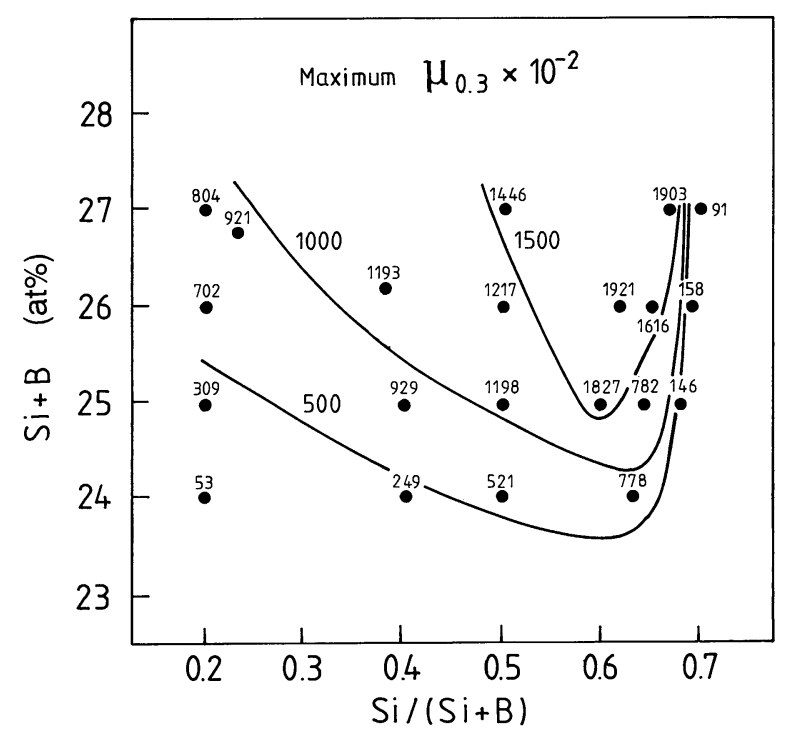

Fig. 10 Change in the maximum $\mu_{0.3}$ at $0.796 \mathrm{~A} / \mathrm{m}$ as a function of $\mathrm{Si}+\mathrm{B}$ and $\mathrm{Si} /(\mathrm{Si}+\mathrm{B})$ for annealed $\left(\mathrm{Co}_{0.94} \mathrm{Fe}_{0.06}\right)_{100-x-y} \mathrm{Si}_{x} \mathrm{~B}_{y}$ amorphous alloys.

the $\mathrm{Si} /(\mathrm{Si}+\mathrm{B})$ range of 0.7 to 0.6 . The compositional dependences of $\mu_{0.3}$ and $H_{\mathrm{c}}$ correspond well to that of $T_{\mathrm{x}}$. That is, the good soft magnetic properties in the high $\mathrm{Si}+\mathrm{B}$ concentration range for the annealed alloys are presumably due to the high thermal stability of the amorphous phase. On the other hand, the ratio of $\mathrm{Si}$ to $\mathrm{Si}+\mathrm{B}$ at which the highest $\mu_{0.3}$ value is obtained is about 0.6 in the as-quenched and annealed states, suggesting that the difference in the noncrystallinity and homogeneity in the as-quenched amorphous structure remains unchanged even after annealing in the temperature range between $T_{\mathrm{c}}$ and $T_{\mathrm{x}}$ because of the high thermal stability. Similarly, the reason why the metalloid composition exhibiting the minimum $H_{\mathrm{c}}$ shifts from $0.6 \mathrm{Si} /(\mathrm{Si}+\mathrm{B})$ in the as-quench- 


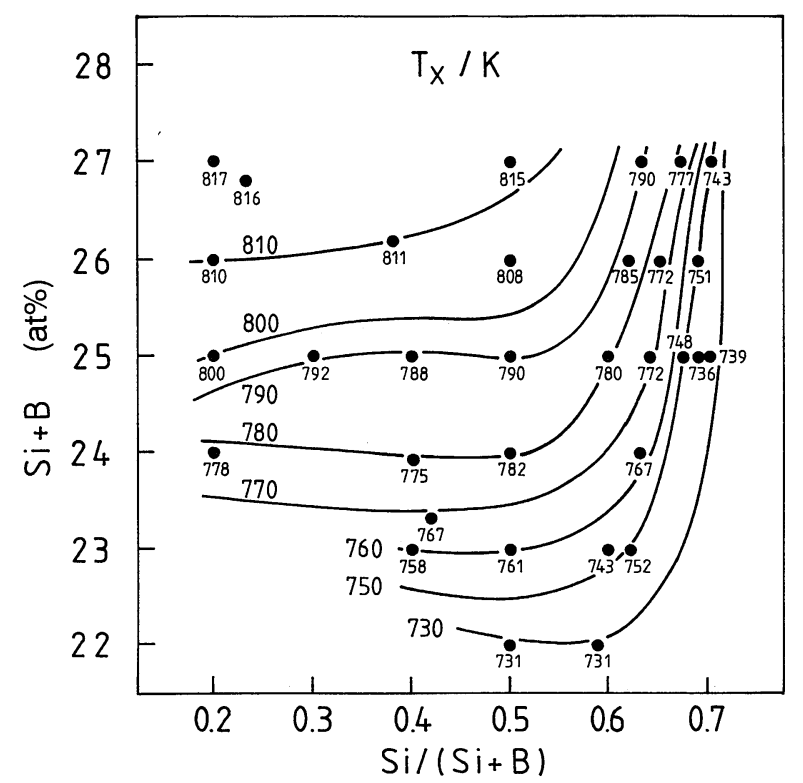

Fig. 11 Change in crystallization temperature $\left(T_{\mathrm{x}}\right)$ as a function of $\mathrm{Si}+\mathrm{B}$ and $\mathrm{Si} /(\mathrm{Si}+\mathrm{B})$ for $\left(\mathrm{Co}_{0.94} \mathrm{Fe}_{0.06}\right)_{100-x-y} \mathrm{Si}_{x} \mathrm{~B}_{y}$ amorphous alloys.

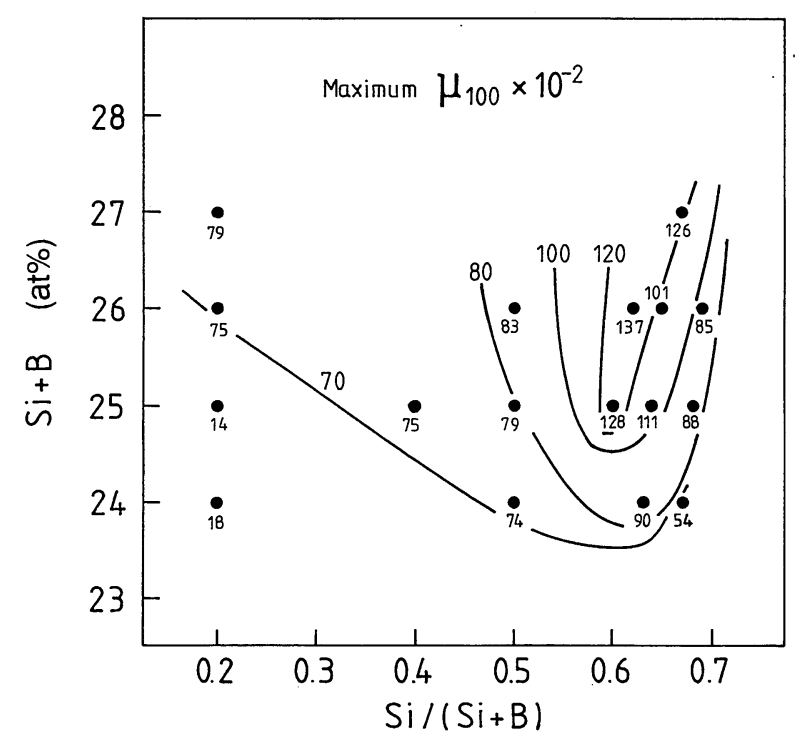

Fig. 12 Change in maximum permeability $\mu_{100}$ at $0.796 \mathrm{~A} / \mathrm{m}$ as a function of $\mathrm{Si}+\mathrm{B}$ and $\mathrm{Si} /(\mathrm{Si}+\mathrm{B})$ for annealed $\left(\mathrm{Co}_{0.94} \mathrm{Fe}_{0.06}\right)_{100-x-y} \mathrm{Si}_{x} \mathrm{~B}_{y}$ amorphous alloys.

ed state to $0.5 \mathrm{Si} /(\mathrm{Si}+\mathrm{B})$ in the annealed state is also due to the higher $T_{\mathrm{x}}$ value in the vicinity of $0.5 \mathrm{Si} /(\mathrm{Si}+\mathrm{B})$ as compared with that at $0.6 \mathrm{Si} /(\mathrm{Si}+\mathrm{B})$.

In addition, Fig. 12 shows the compositional dependence of the maximum permeability at $100 \mathrm{kHz}$ $\left(\mu_{100}\right)$ for $\left(\mathrm{Co}_{0.94} \mathrm{Fe}_{0.06}\right)_{100-x-y} \mathrm{Si}_{x} \mathrm{~B}_{y}$ amorphous alloys subjected to an optimum annealing treatment. The $\mu_{100}$ shows a maximum value of 13700 in the vicinity of $26 \%(\mathrm{Si}+\mathrm{B})$ and $0.6 \mathrm{Si} /(\mathrm{Si}+\mathrm{B})$ and hence the annealing is said to result in the shift of the $\mathrm{Si} /(\mathrm{Si}+\mathrm{B})$ ratio exhibiting the highest $\mu_{100}$ from 0.67 to 0.63 . The shift is also interpreted from the result shown in Fig. 11 that $T_{\mathrm{x}}$ increases with a decrease of $\mathrm{Si} /(\mathrm{Si}+\mathrm{B})$ from 0.7 to 0.6.

\section{(2) Influence of metalloid composition on the saturation magnetization $\left(\sigma_{s}\right)$ and permeability $\left(\mu_{\mathrm{e}}\right)$}

Figure 13 shows the metalloid dependence of $\sigma_{\mathrm{s}}$ for asquenched $\left(\mathrm{Co}_{0.94} \mathrm{Fe}_{0.06}\right)_{100-x-y} \mathrm{Si}_{x} \mathrm{~B}_{y}$ amorphous alloys. The $\sigma_{\mathrm{s}}$ decreases gradually from 105 to $70 \mathrm{emu} / \mathrm{g}$ with an increase of the total metalloid content and the concentration ratio of $\mathrm{Si}$ to $\mathrm{Si}+\mathrm{B}$. The gradual decrease of $\sigma_{\mathrm{s}}$ is thought to originate from the hybridization among $3 \mathrm{~d}-$ electrons in $\mathrm{Co}$ and $\mathrm{Fe}, 3 \mathrm{p}$-electrons in $\mathrm{Si}$ and $2 \mathrm{p}$-electrons in B. On the basis of the data shown in Figs. 10, 12 and 13 on the changes in the $\mu_{0.3}, \mu_{100}$ and $\sigma_{\mathrm{s}}$ with metalloid composition for annealed $\mathrm{Co}-\mathrm{Fe}-\mathrm{Si}-\mathrm{B}$ amorphous alloys, the relations between $\sigma_{\mathrm{s}}$ and $\mu_{0.3}$ or $\mu_{100}$ are shown in Figs. 14 and 15, respectively. The combined

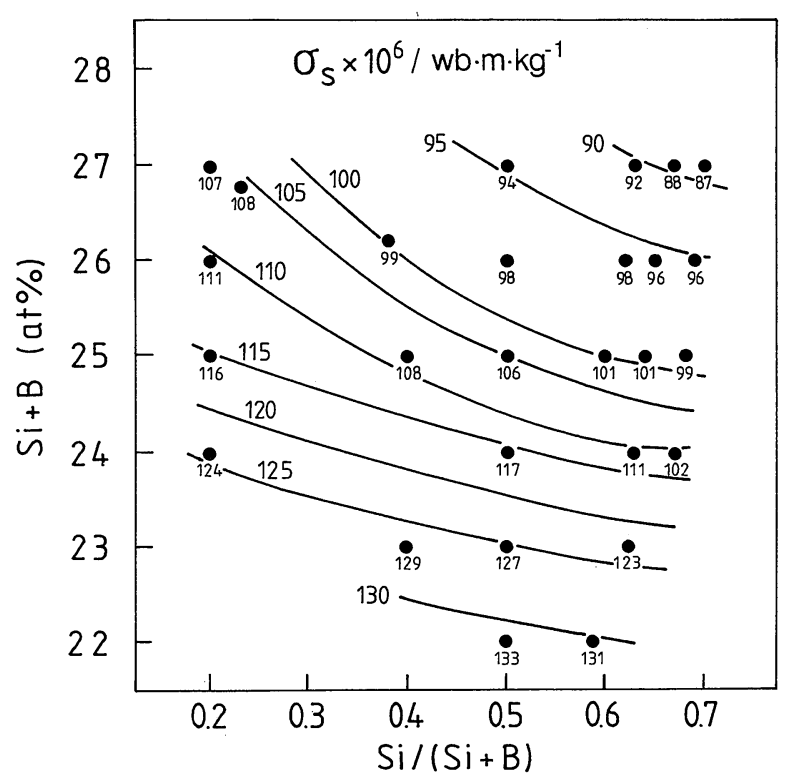

Fig. 13 Change in saturation magnetization $\left(\sigma_{s}\right)$ as a function of $\mathrm{Si}+\mathrm{B}$ and $\mathrm{Si} /(\mathrm{Si}+\mathrm{B})$ for as-quenched $\left(\mathrm{Co}_{0.94} \mathrm{Fe}_{0.06}\right)_{100-x-y} \mathrm{Si}_{x} \mathrm{~B}_{y}$ amorphous alloys.

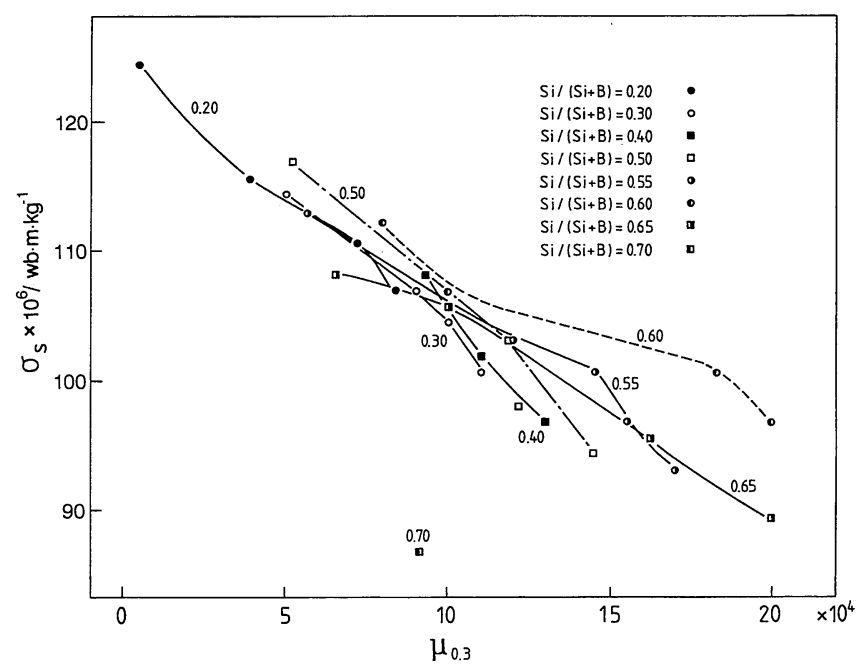

Fig. 14 Relation between $\sigma_{\mathrm{s}}$ and $\mu_{0.3}$ for annealed $\left(\mathrm{Co}_{0.94} \mathrm{Fe}_{0.06}\right)_{100-x-y}$ $\mathrm{Si}_{x} \mathrm{~B}_{y}$ amorphous alloys. 


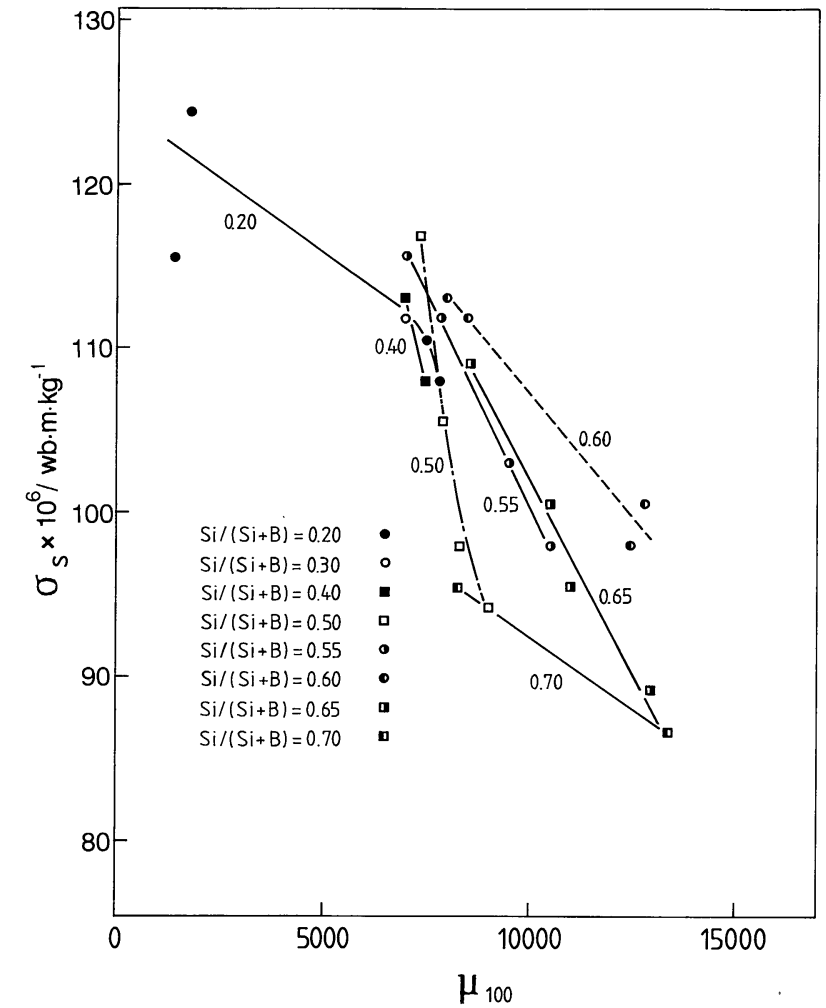

Fig. 15 Relation between $\sigma_{\mathrm{s}}$ and $\mu_{100}$ for annealed $\left(\mathrm{Co}_{0.94} \mathrm{Fe}_{0.06}\right)_{100-x-y}$ $\mathrm{Si}_{x} \mathrm{~B}_{y}$ amorphous alloys.

properties of high $\sigma_{\mathrm{s}}$ and high $\mu_{\mathrm{e}}$ are obtained at both frequencies of 0.3 and $100 \mathrm{kHz}$ for the $\left(\mathrm{Co}_{0.94} \mathrm{Fe}_{0.06}\right)_{100-x-y}$ $\mathrm{Si}_{x} \mathrm{~B}_{y}$ amorphous alloys with $0.6 \mathrm{Si} /(\mathrm{Si}+\mathrm{B})$. It is therefore concluded that the best soft magnetic properties with combined characteristics of high $\sigma_{\mathrm{s}}$, low $H_{\mathrm{c}}$ and high $\mu_{\mathrm{e}}$ at 0.3 and $100 \mathrm{kHz}$ are obtained for $\left(\mathrm{Co}_{0.94} \mathrm{Fe}_{0.06}\right)_{100-x-y} \mathrm{Si}_{x} \mathrm{~B}_{y}$ amorphous alloys with 24 to $27 \%(\mathrm{Si}+\mathrm{B})$ and $0.6 \mathrm{Si} /(\mathrm{Si}+\mathrm{B})$. Here, it is important to describe that the optimum metalloid composition to obtain good soft magnetic properties is completely different from that $(\mathrm{Si} /(\mathrm{Si}+\mathrm{B})=0.2)^{(7)}$ which has been practically used by other groups as soft magnetic materials in Co$\mathrm{Fe}-\mathrm{Si}-\mathrm{B}$ system. The optimum of the alloy composition found in the present study is also supported from the recent trend in which the practical use of magnetic heads made from the amorphous alloy with $0.6 \mathrm{Si} /(\mathrm{Si}+\mathrm{B})$ has increased significantly, in good contrast to the tendency for the amorphous magnetic head with a metalloid composition of $\mathrm{Si} /(\mathrm{Si}+\mathrm{B})=0.2$ to reduce the amount of application $^{(7)}$.

\section{Summary}

In order to search an optimum alloy composition exhibiting excellent soft magnetic properties which are required for an amorphous magnetic head material, the compositional dependences of $\sigma_{\mathrm{s}}, H_{\mathrm{c}}$ and $\mu_{\mathrm{e}}$ were examined for $\mathrm{Co}-\mathrm{Fe}-\mathrm{Si}-\mathrm{B}$ amorphous alloys ranging from 0.9 to $1.0 \mathrm{Co} /(\mathrm{Co}+\mathrm{Fe}), 22$ to $27 \%(\mathrm{Si}+\mathrm{B})$ and 0.2 to
$0.7 \mathrm{Si} /(\mathrm{Si}+\mathrm{B})$. The results obtained are summarized as follows:

(1) Low $H_{\mathrm{c}}$ and high $\mu_{0.3}$ in a rapidly solidified state were obtained for $\mathrm{Co}-\mathrm{Fe}-\mathrm{Si}-\mathrm{B}$ amorphous alloys with $0.94 \mathrm{Co} /(\mathrm{Co}+\mathrm{Fe})$. The lowest $H_{\mathrm{c}}$ and the highest $\mu_{0.3}$ for as-quenched $\left(\mathrm{Co}_{0.94} \mathrm{Fe}_{0.06}\right)_{100-x-y} \mathrm{Si}_{x} \mathrm{~B}_{y}$ amorphous alloys were obtained in the ranges of 25 to $26 \%(\mathrm{Si}+\mathrm{B})$ and $0.6 \mathrm{Si} /(\mathrm{Si}+\mathrm{B})$ and 24 to $25 \%(\mathrm{Si}+\mathrm{B})$ and $0.6 \mathrm{Si} /(\mathrm{Si}+\mathrm{B})$, respectively. The glass-forming capacity in $\mathrm{Co}-\mathrm{Si}-\mathrm{B}$ ternary alloys is the largest in the vicinity of $27 \%(\mathrm{Si}+\mathrm{B})$ and $0.6 \mathrm{Si} /(\mathrm{Si}+\mathrm{B})$, in agreement with that at which the lowest $H_{\mathrm{c}}$ and the highest $\mu_{0.3}$ are obtained. The agreement allows us to presume that the good soft magnetic properties in the limited composition range are due to a high degree of noncrystallinity and homogeneity in the as-quenched amorphous structure. In addition, the $\mu_{100}$ shows a maximum value in the high metalloid range of $27 \%(\mathrm{Si}+\mathrm{B})$ and 0.65 to $0.70 \mathrm{Si} /(\mathrm{Si}+\mathrm{B})$ because of the necessity of high electrical resistivity.

(2) The optimum ratios of $\mathrm{Si} /(\mathrm{Si}+\mathrm{B})$ for $\mu_{\mathrm{e}}$ and $\mathrm{Co} /(\mathrm{Co}+\mathrm{Fe})$ for $\mu_{\mathrm{e}}$ and $H_{\mathrm{c}}$ remain unchanged even after optimum annealing, though the optimum $\mathrm{Si} /(\mathrm{Si}+\mathrm{B})$ ratio for $H_{\mathrm{c}}$ decreases to 0.5 . The compositional effect on the soft magnetic properties for the annealed samples is explained by taking the compositional dependences of noncrystallinity, homogeneity and thermal stability of the amorphous alloys into consideration.

(3) The combined properties of high $\sigma_{\mathrm{s}}$, low $H_{\mathrm{c}}$ and high $\mu_{\mathrm{e}}$ are obtained in the range of 24 to $27 \%(\mathrm{Si}+\mathrm{B})$ and $0.6 \mathrm{Si} /(\mathrm{Si}+\mathrm{B})$ and hence the metalloid composition is concluded to be applicable to an amorphous magnetic head material.

\section{REFERENCES}

(1) H. Fujimori, T. Masumoto, Y. Obi and M. Kikuchi: Jpn. J. Appl. Phys., 13 (1974), 1889.

(2) H. Fujimori, M. Kikuchi, Y. Obi and T. Masumoto: Sci. Rep. Res. Inst. Tohoku Univ., A26 (1976), 36.

(3) S. Ohnuma, K. Watanabe and T. Masumoto: Phys. Status Solidi, (a) 44 (1977), K151.

(4) Y. Makino, K. Aso, A. Uehira, M. Ito and M. Hayakawa: Inst. Electronics, Information Communication Engineers (IEICE) Technical Report, MR78-18 (1978), 39.

(5) T. Ojima, O. Kohmoto, K. Ohya and H. Fujishima: Bulletin of 11th Magnetics Society Japan (MSJ) Topical Symposium, 11-1 (1979), 83.

(6) H. Sakakima, H. Senno, Y. Yanagiuchi and E. Hirota: National Technical Report, 25 (1979), 858.

(7) K. Ohya, N. Ishijima and T. Ojima: Inst. Electronics, Information Communication Engineers (IEICE) Technical Report, CMP81-64 (1981), 1.

(8) Y. Makino: Metals, 9 (1979), 8.

(9) H. Fujimori, K. Arai, H. Shirae, H. Saito, T. Masumoto and N. Tsuya: Jpn. J. Appl. Phys., 15 (1976), 705.

(10) S. Ohnuma and T. Masumoto: J. Appl. Phys., 50 (1979), 7597.

(11) S. Ohnuma and T. Masumoto: Rapidly Quenched Metals III, ed. B. Cantor, The Metals Society, London, (1978), Vol. I, p. 197.

(12) O. Kohmoto, K. Ohya, N. Yamaguchi, H. Fujishima and T. Ojima: J. Appl. Phys., 51 (1980), 4342.

(13) M. Hagiwara, A. Inoue and T. Masumoto: Sci. Rep. Res. Inst. Tohoku Univ., A29 (1981), 351.

(14) T. Takahashi, H. Fujimori and T. Masumoto: private communication, (1977, April). 